\begin{tabular}{|c|c|c|c|c|}
\hline JURNAL & \multirow{2}{*}{ VOLUME 3 } & \multirow{2}{*}{ NOMOR 1 } & HALAMAN 35-40 & $\begin{array}{l}\text { ISSN 2655-8823 }(p) \\
\text { ISSN 2656-1786 }(e)\end{array}$ \\
KOLABORASI RESOLUSI KONFLIK
\end{tabular}

\title{
ANALISIS PENAHAPAN KONFLIK DAN SEGITIGA MULTI TINGKAT DALAM PENYELESAIAN KONFLIK PEMBANGUNAN BANDARA INTERNASIONAL DI MAJALENGKA
}

\author{
Zakiah Alfi Haryani \\ Prodi Ilmu Kesejahteraan Sosial FISIP Universitas Padjadjaran \\ E-mail: zakiah17001@mail.unpad.ac.id \\ Soni Akhmad Nulhaqim \\ Departemen Kesejahteraan Sosial FISIP Universitas Padjadjaran \\ E-mail: soni.nulhaqim@unpad.ac.id
}

\begin{abstract}
ABSTRAK
Penelitian dari konflik bandara internasional di majalengka dilatarbelakangi oleh perbedaan kepentingan antara pemerintah dengan masyarakat setempat yang bermata pencaharian sebagai petani. Tujuan dari penelitian ini adalah untuk menggambarkan tahapan konflik yang terjadi dan menganalisis strategi mengelola konflik yang terjadi. teori yang digunakan adalah teori penahapan konflik dan segitiga multi tingkat dari Simon Fisher dalam bukunya yang berjudul "mengelola konflik". Penelitian ini menggunakan metode penelitian deskriptif dengan teknik pengumpulan data melalui studi literature mengenai isu terkait. Hasil penelitian menunjukan bahwa prakonflik pertama kali dipicu oleh isu penggusuran lahan petani masyarakat sekitar, konfrontasi terjadi ketika pemerintah mengeluarkan surat pengosongan lahan, krisis terjadi ketika terjadi kekerasan dalam pengosongan lahan, akibat dari krisis yang terjadi adalah pemerintah dapat menaklukan masyarakat dengan adanya kompensasi yang diberikan, pascakonflik melibatkan kedua belah pihak yang berdamai dan dilanjutkan dengan pembangunan bandara internasional majalengka yang sekarang sudah dapat beroperasi.
\end{abstract}

Kata Kunci: penahapan konflik, segitiga multi tingkat, mengelola konflik.

\section{PENDAHULUAN}

Konflik merupakan suatu hubungan yang terjadi di antara dua pihak atau lebih (baik individu mau pun kelompok) yang memiliki, atau mereka mengira memiliki tujuan-tujuan yang tidak cocok atau berbeda (Chris Mitchell, 1981: Chapter 1). Konflik akan muncul ketika kedua belah pihak yang berlawanan saling mengejar tujuan yang berbeda tersebut. Ketika sudah mulai timbul ketegangan dan gesekan antara kedua belah pihak yang memiliki tujuan yang berbeda, maka konflik itu sudah mulai terjadi.

Konflik merupakan sebuah fenomena yang tidak dapat dihindarkan dalam kehidupan manusia karena hal tersebut memang merupakan bagian yang inheren dari eksistensi manusia mulai dari tingkat mikro, interpersonal sampai pada tingkat kelompok, organisasi, komunitas, dan negara, semua hubungan antar manusia, baik itu hubungan sosial, hubungan ekonomi, hubungan kekuasaan, dan lain sebagainya. Konflik muncul dari adanya ketidakseimbangan dalam hubunganhubungan tersebut, misalnya ketidakseimbangan dalam kekuasaan yang mengakibatkan munculnya berbagai problematika.

Konflik merupakan sebuah fenomena yang sangat kompleks karena melibatkan dua pihak atau lebih individu maupun kelompok. Walaupun dalam realitasnya sebuah konflik merupakan suatu hal yang kompleks, konflik sendiri tetaplah harus dihadapi dan diselesaikan oleh manusia, baik dalam posisinya sebagai pihak yang terlibat maupun sebagai pihak ketiga yang tidak terlibat namun berusaha membantu pihak yang terlibat agar keluar dari konflik yang sedang terjadi.

Salah satu konflik yang terjadi yang diakibatkan adanya ketidakseimbangan dalam kekuasaan adalah konflik tentang pembangunan bandara internasional di 


\begin{tabular}{|c|c|c|c|c|}
\hline JURNAL & \multirow{2}{*}{ VOLUME 3} & \multirow{2}{*}{ NOMOR 1 } & HALAMAN 35-40 & $\begin{array}{l}\text { ISSN 2655-8823 }(p) \\
\text { ISSN 2656-1786 }(e)\end{array}$ \\
KOLABORASI RESOLUSI KONFLIK & VOLA \\
\hline
\end{tabular}

Majalengka. Pembangunan bandara internasional yang dilakukan pemerintah di Majalengka memerlukan lahan yang sangat luas. Salah satu desa yang terdampak dari adanya pembangunan bandara internasional ini adalah Desa Suka Mulya, Majalengka. 700 hektar lahan yang berada di desa Sukamulya terancam akan digusur demi keberlangsungan pembangunan bandara. Masyarakat desa sukamulya yang sebagian besar bekerja sebagai petani menolak hal tersebut karena lahan yang akan digusur merupakan lahan pertanian yang menjadi sumber penghasilan mereka.

Melansir dari KBR Nasional (2016), Menteri Agraria dan Tata Ruang Sofyan djalil menyatakan bahwa pemerintah tidak akan mengurungkan rencana pembebeasan lahan Desa Sukamulya, Kabupaten Majalengka karena pembangunan runaway Bandar Internasional Jawa Barat tidak bisa menggunakan lahan lain. Keputusan tersebut diambil dengan mempertimbangkan faktor keamanan Bandar Udara. Adanya keputusan tersebut memicu konflik yang terjadi antara pemerintah dan masyarakat Desa Sukamulya itu sendiri. konflik kian memanas ketika terjadi pengukuran lahan paksa yang dilakukan oleh aparat pemerintah. Kekerasan terjadi di dalam proses pengukuran lahan, mulai dari pemukulan, penembakan gas air mata hingga pemadaman listrik. Akibat dari ketegangan kondisi tersebut, terdapat beberapa warga yang mengalami luka-luka dan sebanyak 6 petani ditangkap sebagai provokator berjalannya demonstrasi.

Dari penjelasan yang telah dipaparkan diatas, perlunya diadakan usaha resolusi konflik agar konflik dapat diselesaikan dengan baik dan meminilamalisasi kerugian yang akan diakibatkan oleh adanya konflik tersebut. Analisis penahapan konflik dan segitiga multi tingkat dapat digunakan dalam menganalisis penyelesaian konflik ini. Dengan adanya analisis tersebut, diharapkan dapat menggambarkan kondisi dan situasi konflik yang sedang terjadi dan akhirnya dapat ditemukan solusi yang tepat berdasarkan analisis yang telah dilakukan.

\section{METODE PENELITIAN}

Penelitian ini dilakukan dengan menggunakan metode penelitian deskriptif, yaitu metode yang bertujuan untuk menggambarkan secara detail mengenai kondisi, situasi serta berbagai fenomena yang terjadi. Teknik pengumpulan data yang digunakan dalam penelitian ini adalah metode pengumpulan data studi literatur, yaitu dengan memperlajari penelitianpenelitian terkait melalui karya ilmiah, seperti jurnal/artikel, buku, dan beritaberita mengenai isu terkait.

\section{TINJAUAN KONSEPTUAL Penahapan Konflik}

Fisher menjelaskan Penahapan konflik merupakan salah satu alat bantu dalam menganalisis sebuah konflik yang sedang terjadi. konflik sendiri dapat berubah setiap saat, melalui berbagai tahap aktivitas, intensitas, ketegangan dan kekerasan yang berbeda. Tahap-tahap ini sangat penting untuk diketahui dan digunakan bersama alat bantu untuk menganalisis dinamika dan kejadian yang berkaitan dengan masingmasing tahap konflik. Analisis dasar terdiri dari lima tahap yang umumnya disajikan secara berurutan dan mungkin berulang dalam siklus yang sama. Tahapan- tahapan tersebut adalah:

1. Prakonflik, tahap ini merupakan tahap awal sebelum terjadinya sebuah konflik namun sudah memiliki tendensi terjadinya konflik. Pada tahap ini terdapat suatu ketidaksesuaian sasaran atau tujuan antara dua pihak atau lebih, sehingga dapat menimbulkan terjadinya suatu konflik.

2. Konfrontasi, pada tahap ini konflik sudah menjadi semakin terbuka. Jika hanya ada satu pihak yang merasa adanya suatu masalah, mungkin pendukungnya mulai melakukan aksi demonstrasi. Pada tahap ini pertikaian dan kekerasan 


\begin{tabular}{|c|c|c|c|c|}
\hline $\begin{array}{c}\text { JURNAL } \\
\text { KOLABORASI RESOLUSI KONFLIK }\end{array}$ & VOLUME 3 & \multirow{2}{*}{ NOMOR 1 } & HALAMAN 35-40 & $\begin{array}{l}\text { ISSN 2655-8823 }(p) \\
\text { ISSN 2656-1786 (e) }\end{array}$ \\
\hline
\end{tabular}

mungkin saja untuk terjadi. hubungan di antara kedua belah pihak menjadi sangat tegang, mengarah pada polarisasi di antara para pendukung di masing-masing pihak.

3. Krisis, tahap ini merupakan periode puncak terjadinya sebuah konflik, ketika ketegangan dan/atau kekerasan terjadi sangat parah. Ketika orang-orang dari kedua belah pihak ada yang terbunuh. Komunikasi normal di antara kedua belah pihak sudah terputus. Pernyataan-pernyataan umum cenderung menuduh dan menentang pihak lainnya.

4. Akibat, tahap ini merupakan tahap yang dihasilkan dari tahapan krisis yang terjadi di dalam sebuah konflik. Suatu krisis pasti menimbulkan suatu akibat. Satu pihak mungkin telah menaklukan pihak lainnya, atau mungkin terjadi gencatan senjata. Satu pihak mungkin menyerah atau menyerah atas dasar desakan dari pihak lain. Kedua pihak mungkin setuju untuk melakukan negosiasi, dengan atau tanpa bantuan perantara. Apapun keadaannya, pada tahap ini ketegangan dan kekerasan sudah mulai mengalami penyusutan dalam tahap ini, dan memungkinkan untuk dilakukan penyelesaian konflik.

5. Pasca konflik, tahap ini merupakan keadaan dimana situasi konflik sudah selesai. Sudah tidak ada lagi kekerasan, ketegangan dan hubungan antara kedua pihak sudah mulai kembali normal. Namun, jika isu-isu dari masalah yang timbul karena sasaran mereka yang saling bertentangan tidak dapat diatasi dengan baik, maka akan kembali lagi menjadi situasi pra konflik.

\section{Segitiga Multi Tingkat}

Segitiga multi tingkat diciptakan dalam salah satu kursus "mengelola konflik" untuk memberikan gambaran dan pemahaman yang lebih baik tentang situasi multi tingkat di dalam sebuah konflik. Alat ini merupakan alat analisis konflik yang dikembangkan berdasarkan analisis piramida. Analisis ini merupakan gabungan beberapa piramida yang akan memudahkan kita untuk melihat berbagai tingkat pelaku dalam tiap pihak, dan juga untuk mengetahui bagaimana cara sekelompok pelaku berhubungan atau berinteraksi, baik pada tingkatan yang sama (horizontal), ataupun pada antar tingkat (vertical).

Di dalam buku simon fisher dijelaskan bahwa cara menggunakan alat analisis strategi konflik ini adalah sebagai berikut:

1. Tentukan dua tingkat vertikal atau lebih dalam suatu situasi (misalnya lokal, nasional, internasional atau keluarga, komunitas, regional).

2. Mulailah pada tingkat satu (misalnya lokal) gambarkan segitiga untuk mewakili kelompok atau kelompok kunci pada tingkat tersebut. Tempatkan secara horizontal, ukuran setiap segitiga mewakili kekuatan.

3. Sangat membantu apabila setiap segitiga juga diperlihatkan pelaku tingkat teratas, tengah, dan bawah dalam kelompok tersebut.

4. Ulangi langkah 2 dan 3 pada setiap tingkat vertikal lainnya. Misalnya nasional dengan internasional.

5. Pada setiap tingkat yang lebih tinggi, segitiga-segitiga tersebut dapat ditempatkan di atas dan bersinggungan dengan segitiga yang berhubungan atau berkaitan dengan tingkat bawah.

6. Setelah membuat ilustrasi grafis hubungan multi tingkat, kemudian anda dapat mencoba menjelaskan konflik-konflik spesifik yang terjadi di dalam antar tingkat. Anda juga dapat membuat daftar strategi yang telah digunakan atau mungkin digunakan untuk menyelesaikan konflik-konflik yang ada. 


\begin{tabular}{|c|c|c|c|c|}
\hline $\begin{array}{c}\text { JURNAL } \\
\text { KOLABORASI RESOLUSI KONFLIK }\end{array}$ & VOLUME 3 & \multirow{2}{*}{ NOMOR 1 } & HALAMAN 35-40 & $\begin{array}{l}\text { ISSN 2655-8823 }(p) \\
\text { ISSN 2656-1786 (e) }\end{array}$ \\
\hline
\end{tabular}

HASIL DAN PEMBAHASAN

Analisis Fenomena Konflik dengan Alat Bantu: Penahapan Konflik

1. Prakonflik, berdasarkan yang telah dijelaskan pada tinjauan pustaka, tahap pra konflik merupakan kondisi dimana terdapat perbedaan sasaran atau tujuan dari kedua belah pihak atau lebih, sehingga menyebabkan adanya tendensi terjadinya konflik. Pada kasus pembangunan bandara internasional di majalengka, tahap prakonflik terjadi ketika adanya perbedaan pendapat antara warga sekitar dengan pemerintah mengenai pembangunan bandara itu sendiri. masyarakat sekitar yang bekerja sebagai petani tidak menginginkan lahannya digusur untuk keperluan pembangunan bandara, sedangkan pihak pemerintah berpendapat sebaliknya, mereka ingin melakukan penggusuran lahan pertanian untuk dijadikan lahan pembangunan bandara internasional.

2. Konfrontasi, pada tahap ini konflik sudah menjadi terbuka, apabila hanya ada satu pihak yang menanggapi, maka akan terjadi demonstrasi dari pihak lainnya. Pada tahap ini pertikaian dan kekerasan mungkin saja terjadi. pada kasus pembangunan bandara internasional di majalengka, tahap konfrontasi terjadi dengan adanya demonstrasi yang dilakukan oleh masyarakat sebagai bentuk penolakan terhadap keputusan pemerintah untuk melakukan pembangunan bandara.

3. Krisis, tahap ini merupakan puncaknya dari sebuah konflik. Pada tahap ini pertikaian dan kekerasan yang terjadi paling parah. Pada kasus pembangunan bandara internasional di majalengka, tahap krisis ditandai oleh adanya penggusuran lahan paksa yang dilakukan pihak pemerintah melalui petugas bersenjata yang siap melawan masyarakat yang melakukan penolakan atas penggusuran lahan yang sedang dilakukan. Selain itu, terjadi kekerasan mulai dari pemukulan hingga peluncuran gas air mata yang dilakukan oleh aparat kepada masyarakat yang menolak pengukuran paksa lahan yang akan dijadikan sebagai lahan bandara internasional.

4. Akibat, tahap krisis yang terjadi menghasilkan adanya akibat. Salah satu akibat yang dapat dihasilkan dari adanya tahap krisis adalah salah satu pihak yang telah menaklukan pihak yang lainnya ataupun kedua belah pihak melakukan negoisasi yang dapat meminimalisasi kerugian yang diterima. Pada kasus pembangunan bandara internasional di Majalengka, tahap krisis menyebakan adanya akibat berupa pemerintah tetap memanfaatkan lahan tersebut untuk pembangunan bandara internasional. Negosisasi antara pemerintah dan warga juga dilakukan dalam bentuk kompensasi yang diberikan kepada warga yang lahannya digusur dalam pembanguanan bandara.

5. Pascakonflik, pada tahap ini kondisi sudah mulai membaik. Kekerasan dan pertikaian yang terjadi telah mengalami penyusustan. Pada tahap ini sebanarnya, masih berpotensi untuk terjadi tahap prakonflik kembali, apabila kedua belah pihak kembali berselisih dan tidak ditangani dengan baik. Namun, pada kasus pembangunan bandara internasional di Majalengka tahap pasca konflik berjalan dengan baik dan pembangunan bandaranya pun berhasil untuk dilakukan dan sekarang sudah dapat beroperasi. 


\begin{tabular}{|c|c|c|c|c|}
\hline JURNAL & \multirow{2}{*}{ VOLUME 3} & \multirow{2}{*}{ NOMOR 1 } & \multirow{2}{*}{ HALAMAN 35-40 } & $\begin{array}{l}\text { ISSN 2655-8823 }(p) \\
\text { ISSN 2656-1786 }(e)\end{array}$ \\
\hline
\end{tabular}

\section{Strategi Mengelola Konflik dengan Alat Bantu: Segitiga Multi Tingkat}

Tingkat 1: Masyarakat Desa Sukamulya Tingkat 2: Pemerintah Provinsi Jawa Barat Tingkat 3: Pemerintah Pusat, Presiden Jokowi

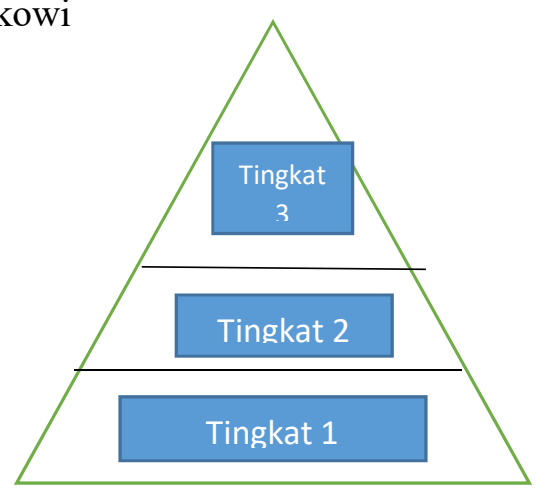

Pada Tingkat 1: Masyarakat Desa Sukamulya

Konflik:

1. Mengenai penggusuran lahan

2. Penolakan Relokasi Desa Suka mulya

Strategi:

1. Diadakan dialog antara masyarakat dan pemerintah provinsi.

2. sosialisasi relokasi lahan yang tergusur

Pada Tingkat 2: Pemerintah Provinsi

Konflik:

1. Demonstrasi yang dilakukan oleh rakyat

Strategi:

1. Melakukan negosiasi dengan masyarakat setempat

Pada Tingkat 3: Pemerintah Pusat

Konflik:

1. Molornya pembangunan bandara internasional yg disebabkan oleh konflik yang terjadi.

Strategi:

1. Menawarkan kompensasi yang sesuai dengan kerugian masyarakat, bukan hanya berupa uang.
KESIMPULAN DAN SARAN

Kesimpulan

Konflik pembangunan bandara internasional yang terjadi di antara pemerintah dengan masyarakat sekitar merupakan salah satu insiden konflik kekerasan karena melibatkan pemaksaan dalam proses penggusuran lahan. Konflik ini bersifat vertikal yang mana konflik terjadi antara dua pihak yang memiliki wewenang dan tingkat kekuasaan yang berbeda. prakonflik pertama kali dipicu oleh isu penggusuran lahan petani masyarakat sekitar, konfrontasi terjadi ketika pemerintah mengeluarkan surat pengosongan lahan, krisis terjadi ketika terjadi kekerasan dalam pengosongan lahan, akibat dari krisis yang terjadi adalah pemerintah dapat bernegosiasi dengan masyarakat dengan adanya kompensasi yang diberikan, pascakonflik melibatkan kedua belah pihak yang berdamai dan dilanjutkan dengan pembangunan bandara internasional Majalengka yang sekarang sudah dapat beroperasi. Secara garis besar, dapat disimpulkan bahwa konflik dapat terjadi karena adanya perbedaan kepentingan dari dua pihak atau lebih.

\section{Saran}

Saran yang dapat diberikan adalah perlunya dilakukan pendekatan tanpa kekerasan dalam melakukan intervensi kepada masyarakat. Selain itu, instansi dan lembaga pemerintahan maupun lembaga sosial untuk lebih baik lagi dalam menjalankan perannya sesuai dengan status masing-masing. Terutama kepada pemerintah yang bertanggung jawab penuh atas rakyatnya. Perundingan antara kedua belah pihak juga sangat diperlukan agar dapat menemukan titik tengah yang dapat menguntungkan kedua belah pihak.

\section{DAFTAR PUSTAKA}

Monogabay (2016, 30 November). Derita petani Desa Sukamulya Kala Terkena Pembangunan Bandara. Diakses pada tanggal 23 Desember 2020 pukul 18.49, melalui 


\begin{tabular}{|c|c|c|c|c|}
\hline JURNAL & \multirow{2}{*}{ VOLUME 3 } & \multirow{2}{*}{ NOMOR 1 } & HALAMAN 35-40 & $\begin{array}{l}\text { ISSN 2655-8823 }(p) \\
\text { ISSN 2656-1786 }(e)\end{array}$ \\
KOLABORASI RESOLUSI KONFLIK
\end{tabular}

https://www.mongabay.co.id/2016/11/ 30/derita-petani-desa-sukamulya-kalaterkena-pembangunan-bandara/

Kompas (2016, $21 \quad$ November). Pembebasan Lahan Bandara Kertajati Dianggap Melanggar UU. Diakses pada tanggal 23 Desember 2020 pukul 18.53, melalui

https://properti.kompas.com/read/2016 /11/21/084411721/pembebasan.lahan.b andara.kertajati.dianggap.melanggar.uu ?page $=$ all

KESBANGPOL (2017, 19 Febuari). Pemetaan Konflik (Conflict Mapping). Diakses pada tanggal 23 Desember 2020 pukul 18.55, melalui https://kesbangpol.inhukab.go.id/index .php/berita-informasi/artikel/18pemetaan-konflik-conflict-mapping

KBR Nasional (2016, 6 Desember). Sengketa Lahan Bandara Kertajati, pemerintah Tetap akan Gusur Desa Sukamulya. Diakses pada tanggal 23 Desember pukul 19.05, melalui Sengketa Lahan Bandara Kertajati, Pemerintah Tetap akan Gusur Desa Sukamulya - kbr.id

Wahyudi, Andri. Konflik, Konsep Teori dan Permasalahan. Diakses pada tanggal 23 Desember 2020 pukul 18.58, melalui

file:///C:/Users/Hp/Downloads/45-821-SM.pdf

Johani, Rianny. 2018. Conflict Stages Between PT Kereta Api and Bandung Citizen. Jurnal Resolusi konflik Unpad Vol. 5, No. 2, Hal 102-110

Fisher, Simon. 2000. Mengelola Konflik: Keterampilan dan Strategi untuk Bertindak. Jakarta: SMK Grafika Desa Putra 